\title{
Pengaruh Antosianin Ubi Ungu terhadap TNF- $\alpha$, Apoptosis dan Memori Spasial Hipokampus Tikus Model Diabetes Melitus
}

\section{Effect of Purple Sweet Potato Anthocyanin towards TNF- $\alpha$, Apoptosis, and Spatial Memory in Hippocampus of Rat Model of Diabetes Mellitus}

\author{
Darwatik $^{1}$, Retty Ratnawati ${ }^{2}$, Sri Rianawati ${ }^{3}$, Imam Sarwono ${ }^{4}$ \\ ${ }^{1}$ Laboratorium Neurologi Rumah Sakit Umum Daerah Saiful Anwar Malang \\ ${ }^{2}$ Laboratorium Fisiologi Molekuler Fakultas Kedokteran Universitas Brawijaya Malang \\ ${ }^{3}$ Laboratorium Neurologi Fakultas Kedokteran Universitas Brawijaya Malang \\ ${ }^{4}$ Laboratorium Patologi Anatomi Fakultas Kedokteran Universitas Brawijaya Malang
}

\begin{abstract}
ABSTRAK
Hiperglikemia pada diabetes melitus menyebabkan penurunan fungsi memori spasial. Terapi yang efektif terhadap gangguan fungsi kognitif akibat hiperglikemia yang sampai saat ini masih dalam perdebatan, menjadikan pendekatan pencegahan menjadi pilihan. Ubi ungu (Ipomoea batatas L.) merupakan tanaman tradisional yang mengandung antosianin, sebagai antiinflamasi, antioksidan, berhubungan dengan peningkatan signalling neuronal otak dalam memperbaiki fungsi memori. Tujuan dari penelitian ini adalah untuk mengetahui pengaruh pemberian antosianin ubi ungu (Ipomoea batatas $L$.) terhadap ekspresi TNF- $\alpha$, apoptosis dan fungsi memori spasial tikus wistar/(Rattus novergicus) model diabetes melitus. Pendekatan ekperimental dilakukan dalam 5 kelompok yaitu kontrol negatif, kontrol positif, antosianin dosis 10, 20, dan 80mg/kgBB selama 6 minggu. Ekspresi TNF- $\alpha$ dan apoptosis diukur menggunakan imunohistokimia, fungsi memori spasial dengan Morris water maze test. Dosis Antosianin 80mg/kgBB menurunkan ekspresi TNF- $\alpha$ dan apoptosis secara bermakna dibandingkan kontrol positif $(p=0,028, p=0,025)$. Dosis $10 \mathrm{dan} 20 \mathrm{mg} / \mathrm{kgBB}$ menurunkan waktu tempuh Morris water maze hari ke 54 pada semua kuadran secara bermakna dibandingkan kontrol positif $(p=0,000)$. Pemberian antosianin dosis $80 \mathrm{mg} / \mathrm{kgBB}$ menurunkan ekspresi TNF- $\alpha$ dan apoptosis sel hipokampus, antosianin dosis 10 dan $20 \mathrm{mg} / \mathrm{kgBB}$ menurunkan waktu tempuh Morris water maze pada tikus wistar/Rattus novergicus model diabetes melitus.
\end{abstract}

Kata Kunci: Antosianin, apoptosis, diabetes melitus, Morris water maze, memori spasial, TNF- $\alpha$

\begin{abstract}
Hyperglycemia in diabetes mellitus leads to decreased spatial memory. Effective therapy against cognitive impairment due to hyperglycemia is still debatable that make a precautionary approach an option. Purple sweet potato is a traditional crop containing anthocyanin that is useful as anti-inflammatory, antioxidant, and associated with increased brain neuronal signaling to improve memory function. This study determined the effect of anthocyanin purple sweet potato towards the expression of TNF- $\alpha$, apoptosis, and spatial memory function in Wistar rats/(Rattus norvegicus) model of diabetes mellitus. This experimental study was performed on 5 groups, namely, negative control, positive control, anthocyanin dose of 10, 20, and $80 \mathrm{mg} / \mathrm{kgBW}$ for 6 weeks. Expression of TNF- $\alpha$ and apoptosis were measured using immunohistochemistry, while spatial memory function was using Morris water maze test. Anthocyanin dose of $80 \mathrm{mg} / \mathrm{kgBW}$ decreased the expression of TNF- $\alpha$ and apoptosis $(p=0,028, p=0,025)$. Dose of $10 \mathrm{and} 20 \mathrm{mg} / \mathrm{kgBW}$ decreased Morris water maze travel time on day 54th in all quadrants significantly compared to positive group $(p=0,000)$. The administration of anthocyanin dose of $80 \mathrm{mg} / \mathrm{kgBW}$ decreased the expression of TNF- $\alpha$ and apoptosis of hippocampal cells, anthocyanin dose of 10 and $20 \mathrm{mg} / \mathrm{kgBW}$ decreased travel time Morris water maze in Wistar rats model of diabetes.
\end{abstract}

Keywords: Anthocyanin, apoptosis, diabetes mellitus, Morris water maze, spatial memory, TNF- $\alpha$

Korespondensi: Darwatik. Laboratorium Neurologi Rumah Sakit Umum Daerah Saiful Anwar Malang, Jl. Jaksa Agung Suprapto no. 2 Malang Tel. (0341) 321397 Email: darwatiksw@gmail.com

DOI: http://dx.doi.org/10.21776/ub.jkb.2018.030.01.3 


\section{PENDAHULUAN}

Jumlah penderita diabetes melitus (DM) selama tiga dekade terakhir, telah mencapai lebih dari dua kali lipat secara global, menjadikan salah satu tantangan kesehatan masyarakat yang paling penting untuk semua bangsa (2). Menurut American Diabetes Association, di Amerika Serikat, prevalensi DM pada tahun 2012 mencapai 29,1 juta jiwa atau 9,3\% populasi dimana 1,2 juta jiwa menderita DM tipe 1 sedangkan untuk penderita prediabetes mencapai 86 juta jiwa. DM merupakan penyebab kematian ketujuh di Amerika Serikat pada tahun 2010 (3). Data RISKESDAS 2013 menunjukkan prevalensi DM berdasarkan klinis di Indonesia sebesar 2,1 persen dengan Jawa Timur berada pada peringkat 4 sebesar 2,1 persen (4).

Diabetes melitus adalah gangguan metabolisme penting yang menyebabkan perubahan fungsional dan struktural dalam sistem saraf pusat. Penelitian sebelumnya menyatakan bahwa gangguan memori, belajar, dan gangguan kognitif lebih umum pada penderita DM dibandingkan pasien non DM (5). Selain itu DM tipe 2 juga meningkatkan insiden demensia Alzheimer dan vaskuler (6). Convit dan coworkers melaporkan bahwa pasien dengan DM tipe 2 mengalami defisit kognitif yang khusus berhubungan dengan kelainan hipokampus yang didukung dengan defisit pada Morris water maze test (sebuah tes untuk memori spasial yang dependen hipokampus) pada hewan coba (7). Disebutkan juga bahwa peradangan saraf yang disebabkan oleh DM yang salah satunya diperankan oleh TNF- $\alpha$ berkontribusi dalam produksi $A \beta$ (beta Amyloid) dan hiperfosforilasi protein tau serta berhubungan dengan gangguan memori $(8,9)$.

Hiperglikemia telah terbukti menyebabkan peradangan di otak. Bukti menunjukkan bahwa terjadi akumulasi mediator inflamasi dalam otak penderita diabetes (5). Disebutkan bahwa peradangan saraf yang disebabkan oleh diabetes melitus memainkan peran penting dalam produksi $A \beta$ (beta Amyloid) dan hiperfosforilasi protein tau (8). NFkB memainkan peran sentral dalam inisiasi dan amplifikasi inflamasi dengan memberi rangsangan sitokin proinflamasi seperti TNF- $\alpha$ atau interleukin-1 (IL-1) (9). Hiperglikemia mengganggu struktur sinaptik dan menginduksi apoptosis neuronal yang ditunjukkan dengan meningkatnya pewarnaan sel TUNEL positif pada hipokampus tikus diabetes melitus. Pada akhirnya terjadi kerusakan morfologi dan fungsional hipokampus serta plastisitas sinaptik in vivo dan di vitro (10).

Belum terdapat terapi efektif untuk demensia. Kajian lebih difokuskan dalam upaya pencegahan demensia termasuk perlindungan otak seperti peningkatan faktor neurotropik terkait dengan neurotransmisi, plastisitas sinaptik, dan eliminasi dari 6-amyloid dari otak (11). Antosianin termasuk dalam kelompok flavonoid yang memiliki kelompok fenolik pada struktur kimiawinya dan memberikan warna pada beberapa bunga dan buah (12). Antosianin merupakan antioksidan yang poten (13) sehinga berperan sebagai neuroprotektan (14). Penelitian untuk meneliti efek antioksidan dan antiinflamasi antosianin pada tikus model Alzheimer menunjukkan bahwa antosianin memberikan efek pada fungsi kognitif tikus model tersebut (15). Penelitian untuk mengamati efek antosianin terhadap fungsi kognitif tikus model diabetes belum banyak dilakukan. Penelitian ini dilakukan untuk mengetahui pengaruh pemberian antosianin pada fungsi kognitif tikus model hiperglikemia dengan parameter fungsi memori spasial dan ekspresi TNF- $\alpha$ sebagai penanda inflamasi serta apoptosis pada sel hipokampus otak.

\section{METODE}

Penelitian menggunakan desain eksperimental laboratorik, post-test only control group dengan menggunakan tikus wistar yang diinduksi hiperglikemia. Subjek dibagi 5 kelompok, yaitu: kelompok A (kontrol negatif), kelompok B (kontrol positif), kelompok C (antosianin 10mg/kgBB), kelompok D (antosianin $20 \mathrm{mg} / \mathrm{kgBB}$ ), dan kelompok E (antosianin $80 \mathrm{mg} / \mathrm{kgBB}$ ). Pembedahan dilakukan pada minggu ke-7 setelah pemberian diet tinggi lemak.

Penelitian dilakukan di Laboratorium Farmakologi, Patologi Anatomi dan Fisiologi Fakultas Kedokteran Universitas Brawijaya Malang. Sampel penelitian adalah tikus wistar jantan berat 150-250gram, umur 6-8 minggu yang didapat dari Eijkman Institute Jakarta. Penelitian dilakukan pada bulan Juni 2016-Oktober 2016 dan disetujui oleh komisi etik Fakultas Kedokteran Universitas Brawijaya Malang.

\section{Induksi Diabetes}

Tikus wistar diberikan diet tinggi lemak selama 6 minggu dan injeksi streptozotocin intraperitonial dengan dosis $30 \mathrm{mg} / \mathrm{kg}$ pada akhir minggu ketujuh dan $30 \mathrm{mg} / \mathrm{kg} 24$ jam setelah injeksi pertama. Diet tinggi lemak terdiri dari PARS $50 \%$, tepung terigu $25 \%$, kolesterol $1 \%$, asam cholat $0,1 \%$, minyak babi $2,5 \%$, dan air $21,4 \%$. Diet tinggi lemak diberikan pada minggu 2-7.

\section{Pemberian Antosianin Ubi Ungu (Ipomoea batatas L.)}

Pemberian antosianin menggunakan antosianin melalui proses purifikasi ubi jalar ungu (Ipomoea batatas L.), yang berasal dari ubi jalar ungu kultivar Gunung Kawi yang dilakukan oleh Dr. Ciptati, MS., di Laboratorium Kimia FMIPA ITB Bandung. Purifikasi dilakukan dengan menggunakan kromatografi kolom flash termodifikasi dengan fasa diam poliamida CC- 6 dan fasa gerak air dan etanol. Pemberian ekstrak antosianin diberikan secara oral satu kali setiap hari selama 6 minggu dengan dosis 10, 20 dan $80 \mathrm{mg} / \mathrm{kgBB}$ (16).

\section{Pengambilan Sampel Otak}

Tikus wistar dimatikan dengan pemberian eter perinhalasi. Tikus dipastikan tidak sadar atau tidak menunjukkan gerakan spontan kemudian dilakukan pengambilan jaringan otak tikus dengan melalukan pembedahan kranium. Pembedahan tersebut dilakukan dengan cara menggunting kranium dengan arah sagital dari kaudal (oksipital) menuju ke rostral (frontal), tepat diantara kedua hemisfer otak tikus. Selanjutnya dilakukan pembebasan otak tikus pada regio basal dari jaringan ikat sekitarnya. Hemisfer otak kanan dan kiri dipisahkan kemudian diambil hemisfer otak sisi kiri, dimasukkan kedalam botol yang telah diisi larutan formalin $10 \%$ dan hemisfer sisi kanan dimasukkan ke dalam plastik untuk dilakukan pemeriksaan MDA. Botol yang berisi hemisfer kiri otak tikus dan larutan formalin tersebut selanjutnya ditutup rapat. Tahap selanjutnya adalah melakukan pemotongan jaringan otak dan pembuatan slide dengan paraffin block yang dilakukan di Laboratorium Patologi Anatomi Fakultas Kedokteran Universitas Brawijaya.

\section{Deparafinisasi}

Jaringan otak dimasukkan tabung formalin $10 \%$ dipotong dengan rotary mikrotom setebal 4 mikron dan diletakkan dalam poly-L-lysine dan dibiarkan dalam suhu kamar. Selanjutnya dilakukan deparafinisasi, tetapi sebelumnya slide dipanaskan dahulu pada suhu $60^{\circ} \mathrm{C}$ selama 60 menit. Dilakukan penambahan larutan berikut secara berurutan: 
xilol (2x10 menit), etanol absolut (2x10 menit), etanol 90\% (1x5 menit), etanol 80\% (1x5 menit), etanol 70\% (1x5 menit), akuades steril ( $3 \times 5$ menit).

\section{Pemeriksaan Ekspresi TNF- $\alpha$}

Sebelum dilakukan pemeriksaan Ekspresi TNF- $\alpha$ dibawah mikroskop cahaya oleh peneliti dan dua orang peneliti lain dalam satu bidang, serta satu orang ahli patologi anatomi, terlebih dahulu dilakukan proses bertahap pengecatan. Slide dicuci dengan PBS pH 7,4 satu kali selama 5 menit kemudian dilakukan bloking peroksida endogen menggunakan $\mathrm{H} 2 \mathrm{O} 2$ 3\% selama 20 menit. Selanjutnya slide dicuci menggunakan PBS dengan $\mathrm{pH}$ 7,4 sebanyak tiga kali, selama 5 menit. Protein yang tidak spesifik di blok menggunakan FBS $5 \%$ yang mengandung $0,25 \%$ Triton X100. Sebelum dan sesudah slide diinkubasi menggunakan rabbit poliklonal anti TNF- $\alpha$, selama 60 menit, slide dicuci terlebih dahulu menggunakan PBS pH 7,4 tiga kali, selama 5 menit. Setelah itu dilakukan inkubasi menggunakan anti rabbit HRP conjugated selama 40 menit. Kemudian dilakukan pencucian menggunakan PBS pH 7,4 tiga kali, selama 5 menit. Selanjutnya slide ditetesi dengan DAB (Diamino Benzidine) dan diinkubasi selama 10 menit kemudian dicuci menggunakan PBS $\mathrm{pH} 7,4$ tiga kali, selama 5 menit. Tahap selanjutnya adalah pencucian menggunakan $\mathrm{dH} 20$, selama 5 menit kemudian dilakukan counterstaining menggunakan Mayer Hematoxilen dan diinkubasi selama 10 menit serta dicuci menggunakan tap water. Tahap terakhir adalah pembilasan dengan $\mathrm{dH} 2 \mathrm{O}$ kemudian dikering anginkan sebelum dimounting menggunakan entelan dan ditutup dengan cover glass.

\section{Pengamatan Sel Apoptosis}

Pengamatan sel apoptosis dilakukan menggunakan antibodi TUNEL apoptosis dimana ada beberapa tahap yang harus dilakukan untuk menghasilkan gambaran imunohistokimia yang kemudian dapat diamati dibawah mikroskop cahaya. Slide dicuci menggunakan PBS pH 7,4 kemudian dinkubasi dengan $20 \mathrm{ug} / \mathrm{mL}$ proteinase- $\mathrm{K}$ selama 15 menit pada $37^{\circ} \mathrm{C}$. Selanjutnya slide dicuci menggunakan PBS pH 7,4 tiga kali, masing-masing selama 5 menit sebelum dan sesudah diinkubasi pada $\mathrm{H} 2 \mathrm{O} 23 \%$ selama 15 menit. Tahap berikutnya adalah inkubasi menggunakan Tunel fragmented DNA labeling (enogene) selama 60 menit pada $37^{\circ} \mathrm{C}$. Selanjutnya slide dicuci menggunakan PBS pH 7,4 tiga kali, masing-masing selama 5 menit. Setelah itu dilakukan inkubasi dengan peroksidase solution selama 40 menit pada $37^{\circ} \mathrm{C}$. Kemudian dicuci lagi menggunakan PBS pH 7,4 tiga kali, masing-masing selama 5 menit dan ditetesi menggunakan substrat untuk Peroksidase (DAB-DiaminoBenzidine) selama 20 menit pada suhu ruang. Tahap akhir adalah pencucian menggunakan PBS $\mathrm{pH} 7,4$ sebelum dilakukan Counterstain dengan Mayer hematoxilen selama 10 menit kemudian dibilas dengan air kran dan dicuci dengan $\mathrm{dH} 2 \mathrm{O}$, dikeringkan dan ditutup cover glass. Kemudian slide diamati dibawah mikroskop cahaya dengan pembesaran 100x, kemudian 400x, sel-sel apoptosis ditunjukkan dengan warna coklat pada inti sel. Pemeriksaan dilakukan oleh penulis, dua peneliti lain dalam satu bidang dan satu orang ahli patologi anatomi.

\section{Pemeriksaan Morris water maze}

Pengenalan metode Morris water maze dilakukan dengan latihan berenang pada hewan coba untuk mencapai landasan. Pengenalan berupa latihan sebanyak satu kali sehari dengan posisi awal berenang dipindah-pindah, sedangkan posisi landasan yang dituju tetap (pada kuadran lima) sesuai dengan pembagian kuadran. Terdapat empat rute yang harus ditempuh masing masing tikus, yaitu Kuadran I, II, III, IV dengan waktu tempuh maksimal dalam proses mencari landasan yang dituju adalah selama 120 detik, serta diperkenankan berada diatas landasan selama maksimal lima belas detik (17).

Tes pengenalan dilakukan selama tiga hari yaitu hari ke 4 sampai dengan hari keenam. Setiap selesai melakukan tes tikus akan diletakkan dalam kandang transit yang diletakkan pada ruangan terbuka dan dikeringkan selama lima belas menit menggunakan hair dryer dan handuk sebelum dimasukkan kembali kedalam kandang. Hal ini mempunyai tujuan agar menghindari terjadinya hipotermia. Untuk kebersihan alat coba, air dalam bejana dibuang kemudian bejana dicuci dengan desinfektan serta dikeringkan untuk menghindari adanya organisme infeksius (17).

Selama tiga hari pertama percobaan, hewan coba tikus hanya diberi pakan standar dan dibiarkan beradaptasi terhadap lingkungan kandang, pada hari keempat mulailah seluruh hewan coba diberi pengenalan pada perangkat Morris water maze sebanyak satu kali sehari selama tiga hari sesuai metode pengenalan terhadap lingkungan pada awal percobaan. Pada akhir sesi pengenalan alat sebelum dilakukan perlakuan, dihitung rerata waktu tempuh oleh orang lain selain peneliti (untuk menghilangkan bias penelitian) dari masing masing kelompok pada hewan coba. Pada akhir perlakuan (pada awal minggu ke delapan) dilakukan tes Morris water maze dan dilakukan perhitungan kembali rerata waktu tempuh pada kelima kelompok hewan coba (17).

\section{Analisa Statistik}

Semua data yang diperoleh dalam penelitian ini dilakukan analisis dengan menggunakan metode statistik one-way ANOVA yang dilanjutkan dengan Pemeriksaan LSD Post Hoc untuk membandingkan perbedaan lebih dari dua kelompok. Hasil uji statistik signifikan jika nilai $p<0,05$.

\section{HASIL}

Efek pemberian antosianin pada Ekspresi TNF- $\alpha$ pada Sel Hipokampus
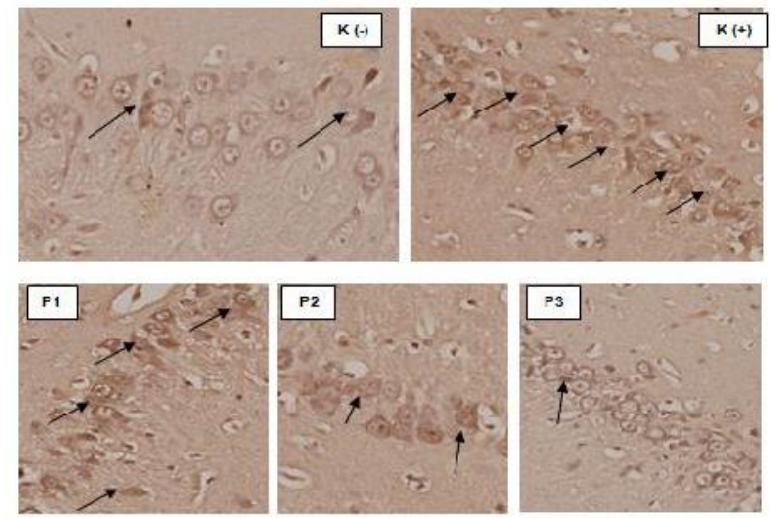

Gambar 1. Gambaran ekspresi TNF- $\alpha$ sel hipokampus otak tikus wistar/Rattus novergicus menggunakan teknik imunohistokimia pada kelompok kontrol dan perlakuan pada hari ke-54

Keterangan: $\mathrm{K}(-)$ : kontrol negatif; $\mathrm{K}(+)$ : kontrol positif; $\mathrm{P} 1$ : antosianin dosis $10 \mathrm{mg} / \mathrm{kgBB}$; P2: antosianin dosis $20 \mathrm{mg} / \mathrm{kgBB}$; P3: antosianin dosis $80 \mathrm{mg} / \mathrm{kgBB}$. Tanda panah menunjukkan sel dengan ekspresi TNF- $\alpha$ 
Gambar 1 menunjukkan gambaran ekspresi TNF- $\alpha$ hasil pengecatan imunohistokimia pada sel hipokampus otak tikus wistar pada kelompok kontrol dan perlakuan pada hari ke 54. Pada kelompok kontrol positif $\mathrm{K}(+)$ lebih banyak sitoplasma yang tercat warna coklat, menunjukkan pada kelompok kontrol positif $\mathrm{K}(+)$ terdapat ekspresi TNF- $\alpha$ yang lebih banyak dibanding kelompok kontrol negatif $\mathrm{K}(-)$. Pada kelompok perlakuan 1,2,3 (P1), (P2), (P3) gambaran ekspresi TNF- $\alpha$ semakin menurun secara berurutan.

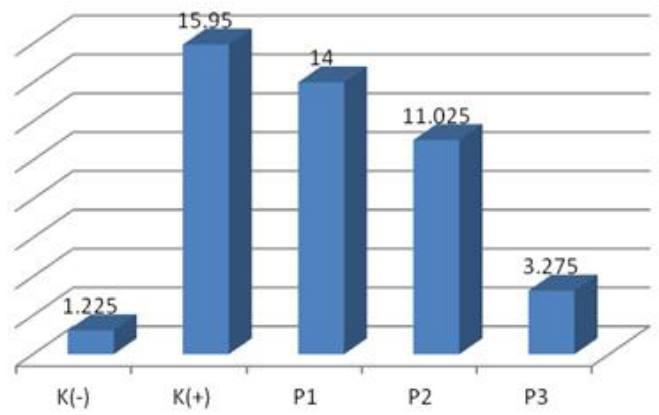

m TNFAlfa

Gambar 2. Grafik Perbandingan ekspresi TNF- $\alpha$ sel hipokampus otak tikus wistar/Rattus novergicus menggunakan teknik imunohistokimia pada kelompok kontrol dan perlakuan pada hari ke-54

Keterangan: $\mathrm{K}(-)$ : kontrol negatif; $\mathrm{K}(+)$ : kontrol positif; P1: antosianin dosis $10 \mathrm{mg} / \mathrm{kgBB}$; P2: antosianin dosis $20 \mathrm{mg} / \mathrm{kgBB}$; P3: antosianin dosis $80 \mathrm{mg} / \mathrm{kgBB}$

Gambar 2 menunjukkan bahwa rata-rata ekspresi TNF- $\alpha$ tertinggi terdapat pada kelompok yang diberikan diet tinggi lemak dan injeksi streptozotocin $(\mathrm{K}+)$ dan rata-rata ekspresi TNF- $\alpha$ terendah terdapat pada kelompok tanpa perlakuan (K-). Peningkatan dosis antosianin pada kelompok P1, P2, P3 menunjukkan penurunan rata-rata ekspresi TNF- $\alpha$ secara berurutan. Hasil analisis uji statistic one-way ANOVA menunjukkan perbedaan yang nyata antar perlakuan. Uji post hoc Tukey ekspresi TNF- $\alpha$ terhadap kelompok $\mathrm{K}(+)$, P1, P2, P3 pada hari ke 54 menunjukkan hanya pada dosis $80 \mathrm{mg} / \mathrm{kgBB}$ pemberian antosianin dapat menurunkan ekspresi TNF- $\alpha$ sel hipokampus otak tikus wistar/Rattus novergicus model diabetes melitus secara bermakna.

Efek Pemberian Antosianin pada Ekspresi Apoptosis pada Sel Hipokampus
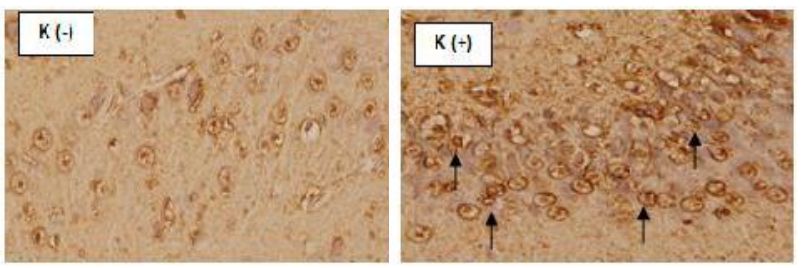

Gambar 3. Gambaran apoptosis sel hipokampus otak tikus wistar/Rattus novergicus menggunakan teknik imunohistokimia pada kelompok kontrol dan perlakuan pada hari ke-54
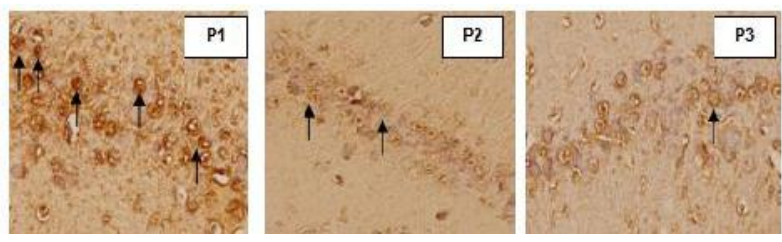

Gambar 3. Gambaran apoptosis sel hipokampus otak tikus wistar/Rattus novergicus menggunakan teknik imunohistokimia pada kelompok kontrol dan perlakuan pada hari ke-54 (Lanjutan)

Keterangan: $\mathrm{K}(-)$ : kontrol negatif; $\mathrm{K}(+)$ : kontrol positif; P1: antosianin dosis $10 \mathrm{mg} / \mathrm{kgBB}$; P2: antosianin dosis 20mg/kgBB; P3: antosianin dosis $80 \mathrm{mg} / \mathrm{kgBB}$

Gambar 3 menunjukkan bahwa pada kelompok kontrol positif $\mathrm{K}(+)$ terdapat gambaran ekspresi apoptosis yang lebih banyak dibanding kelompok kontrol negatif K(-). Pada kelompok perlakuan (P1), (P2), (P3) gambaran ekspresi apoptosis semakin menurun.

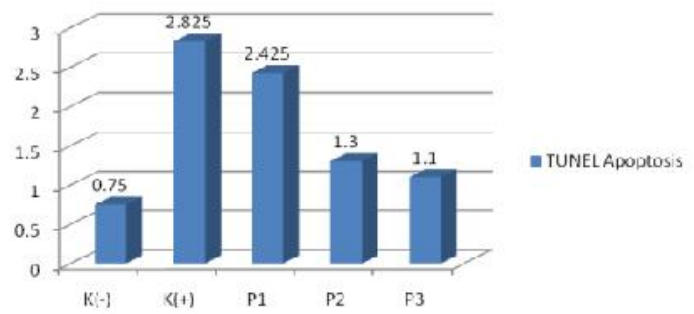

Gambar 4. Grafik rata- rata apoptosis sel hipokampus otak tikus wistar/Rattus novergicus pada kelompok kontrol dan perlakuan pada hari ke-54.

Keterangan: K(-): Kontrol negatif; $\mathrm{K}(+)$ : Kontrol positif; P1: Antosianin dosis $10 \mathrm{mg} / \mathrm{kgBB} ; \mathrm{P2}$ : Antosianin dosis $20 \mathrm{mg} / \mathrm{kgBB}$; P3: Antosianin dosis $80 \mathrm{mg} / \mathrm{kgBB}$

Gambar 4 menunjukkan rata-rata apoptosis tertinggi terdapat pada kelompok $\mathrm{K}(+) /$ kontrol positif yaitu kelompok yang diberikan diet tinggi lemak dan injeksi streptozotocin. Pada kelompok perlakuan peningkatan dosis antosianin memberikan rata-rata apoptosis yang menurun berurutan, dengan perbedaan terbesar dimulai pada perlakuan 2. Hasil uji one-way ANOVA $(p=0,007)$ menunjukkan terdapat perbedaan apoptosis yang nyata antar perlakuan. Uji Post Hoc Tukey menunjukkan bahwa hanya perlakuan dosis $80 \mathrm{mg} / \mathrm{kbBB}$ yang dapat menurunkan apoptosis sel hipokampus otak tikus wistar model diabetes melitus secara bermakna $(p=0,025)$.

Fungsi MemoriSpasial

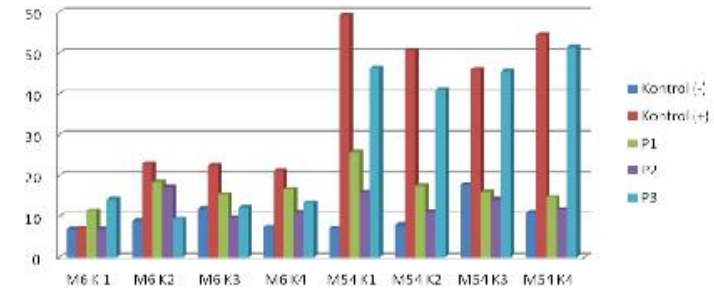

Gambar 5. Grafik rata-rata waktu tempuh Morris water maze Keterangan: $\mathrm{K}(-)$ : Kontrol negatif; $\mathrm{K}(+)$ : Kontrol positif; $\mathrm{P} 1$ : Antosianin dosis 10 $\mathrm{mg} / \mathrm{kgBB}$; P2: Antosianin dosis $20 \mathrm{mg} / \mathrm{kgBB}$; P3: Antosianin dosis $80 \mathrm{mg} / \mathrm{kgBB}$ 
Gambar 5 menunjukkan perbandingan waktu tempuh Morris water maze pada hari ke-6 tidak terdapat perbedaan besar antar kelompok pada semua kuadran. Waktu tempuh terendah dan tertinggi juga berbeda-beda setiap kuadran. Hal ini menunjukkan bahwa semua hewan coba memiliki karakter yang sama dalam menempuh Morris water maze sebelum diberikan perlakuan. Pada hari ke-54, pada semua kuadran waktu tempuh Morris water maze yang paling rendah adalah pada kelompok dengan pemberian antosianin $20 \mathrm{mg} / \mathrm{kgBB}$.

Hasil uji post hoc Tukey waktu tempuh Morris water maze pada semua kuadran terhadap kelompok K(+), P1, P2, P3 pada hari ke 54 menunjukkan bahwa pemberian dosis antosianin dosis $10 \mathrm{mg} / \mathrm{kgBB}$ (P1) dan 20mg/kgBB (P2) memberikan penurunan signifikan dibandingkan kondisi DM $(\mathrm{K}+)$ disemua kuadaran. Pada dosis $80 \mathrm{mg} / \mathrm{kgBB}$ tidak ditemukan perbedaan waktu tempuh yang bermakna.

\section{DISKUSI}

Antosianin Menurunkan Ekspresi TNF- $\alpha$, Apoptosis Hipokampus Otak dan Memperbaiki Memori Spasial Tikus Wistar/(Rattus novergicus) Model Diabetes Melitus

Pada penelitian ini pemberian total antosianin dapat menurunkan ekspresi TNF- $\alpha$ pada dosis $80 \mathrm{mg} / \mathrm{kgBB}$. Hal ini dimungkinkan karena efek antiinflamasi dari antosianin (15). Penelitian sebelumnya dengan pemberian grape seed extract (GSE) yang mengandung antosianin menurunkan ekspresi TNF- $\alpha$ pada tikus diabetes yang diinduksi streptozotocin dengan nuclear factor kB (NFkB) yang memegang peran penting dalam mekanisme selulernya (5). Penelitian lain juga menyebutkan bahwa prosianidin dari grape seed extract (GSE) menghambat aktivasi NFkb sehingga menurunkan ekspresi TNF- $\alpha$ dan IL-6 (18). Pada penelitian ini antosianin baru memberikan perbedaan secara signifikan ekspresi TNF- $\alpha$ pada otak tikus wistar/Rattus novergicus model diabetes melitus pada dosis $80 \mathrm{mg} / \mathrm{kgBB}$. Penelitian lain dengan dosis $100 \mathrm{mg} / \mathrm{kgBB}$ pemberian antosianin pada tikus yang diinduksi $D$ galaktosa untuk menghasilkan stres oksidatif terbukti menghambat aktivasi NFkB dan menurunkan ekspresi TNF- $\alpha$ pada hipokampus dan korteks (19).

Pemberian total antosianin dapat menurunkan apoptosis hipokampus pada dosis $80 \mathrm{mg} / \mathrm{kgBB}$. Hal ini disebabkan oleh efek antioksidan antosianin yang memiliki efek penghambatan kerusakan DNA neuron hipokampus akibat stress oksidatif dan menurunkan ekspresi gen proapoptosis. Selain itu juga terjadi penghambatan aktivasi NFkB yang dapat menginduksi apoptosis sel neuron (5). Penggunaan antosianin pada kultur sel neuron hipokampus tikus yang diinduksi dengan asam kainat dimana antosianin dapat menghambat $\mathrm{Bcl} 2$ dan meningkatkan Bax sehingga mencegah apoptosis yang diidentifikasi dengan pengecatan TUNEL, yang menunjukkan antosianin berperan sebagai antioksidan (20). Penelitian lain menunjukkan penggunaan Rabbit-eye Blueberry pada tikus yang diinduksi trymethilen sehingga timbul neurotoksisitas dengan antosianin berperan menjaga integritas membran plasma sel otak dan mencegah terjadinya apoptosis (21).

Perbaikan memori spasial pada penelitian ini ditemukan pada perlakuan dosis $10 \mathrm{mg} / \mathrm{kgBB}$ dan $20 \mathrm{mg} / \mathrm{kgBB}$. Perbaikan fungsi memori spasial yang ditunjukkan oleh rendahnya waktu tempuh Morris water maze ini disebabkan oleh efek antiinflamasi, antioksidan dan signaling neuronal dari antosianin pada hipokampus yang mampu memperbaiki fungsi memori (22). Pemberian pelargonidin, salah satu bentuk antosianin, sebesar $10 \mathrm{mg} / \mathrm{kgBB}$ dosis tunggal pada tikus wistar yang diinduksi diabetes melitus terbukti memperbaiki fungsi memori spasial dengan $Y$-Maze task dan pemberian dosis multipel mencegah abnormalitas retensi dan recall. Mekanisme tersebut terjadi melalui penurunan radikal bebas yang memicu peroksidasi lipid pada otak yang berpengaruh pada fungsi kognitif. Pelargonidin juga berperan sebagai antihiperglikemia. Hiperglikemia meningkatkan jalur sorbitol sehingga menurunkan taurin intraseluler yang merupakan faktor neurotropik dan jalur poliol yang dapat menurunkan inositol yang merupakan komponen mayor fosfolipid yang memproduksi neurotransmitter (23). Penelitian lain dengan ekstrak blueberry yang mengandung 179 mikrogram perhari selama 6 minggu juga menunjukkan perbaikan fungsi memori spasial melalui aktivasi jalur ERK-CREB-BDNF yang merupakan jalur untuk kontrol plastisitas sinaptik (24).

Penelitian lain melaporkan bahwa asupan total antosianin plum dan blackberry menghambat perburukan fungsi neuron dan mengembalikan fungsi memori dan motorik (23). Efek antosianin ini kemungkinan diperantarai oleh penghambatan inflamasi neuron. Sebagai contoh, antosianin diketahui menghambat upregulasi (NFkB) pada tikus Fischer. Asupan blueberry akan menghambat kerusakan fungsi kognitif dan memori yang diinduksi oleh asam kainic, melalui hambatan ekspresi IL-1b, TNF $\alpha$, dan nuclear factor-kB di hipokampus (23). Antosianin juga diketahui dapat mencegah terjadinya resistensi insulin dan hiperglikemia sehingga mencegah kerusakan neuron. Insulin berperan penting dalam proses memori. Dalam belajar dan memori, insulin memodulasi sinaptik plastisitas dengan bertindak pada reseptor glutamatergic dan GABAergic. Pada hipotalamus, insulin dapat memainkan peran tidak langsung pada regulasi metabolisme glukosa perifer, proses belajar, dan memori terutama yang terletak di hipokampus. Peran ini lebih cenderung disebabkan oleh modulasi langsung dari aktivitas reseptor di neuron dan sel-sel glia. Bukti telah menunjukkan bahwa signal insulin memainkan peran penting dalam sinaptik plastisitas dengan bertindak pada transmisi kedua glutamatergic dan gamma-aminobutyric acid (GABA). Terpaparnya reseptor $N$-methyl-D-aspartic acid (NMDA) menyebabkan insulin dalam waktu singkat memicu dengan cepat terhadap tanggapan potensial dari NMDA, yang dapat dimediasi oleh subtipe reseptor NMDA. Reseptor NMDA berperan penting pada sinaptik plastisitas dalam pembelajaran dan pembentukan memori (25).

Pada dosis total antosianin $80 \mathrm{mg} / \mathrm{kgBB}$, tidak memberikan penurunan bermakna fungsi memori spasial meskipun pada dosis tersebut mampu menurunkan ekspresi TNF- $\alpha$ dan apoptosis sel hipokampus. Pada dosis ini mungkin tidak dapat menunjang fungsi lain yang berperan pada terbentuknya memori spasial selain hipokampus seperti mammillary bodies, dorsal tegmental nuclei, subiculum, parasubiculum and the entorhinal cortex (26). Pada penelitian lain dengan pemberian pelargonidin dosis multipel tidak memperbaiki memori spasial akibat stres yang berasal dari gavage needle yang mempengaruhi jalur kolinergik yang merusak beberapa aspek pada memori spasial (23). 
Dalam penelitian ini pada saat pemeriksaan Morris water maze peneliti harus mengambil video secara manual yang dapat mempengaruhi perilaku hewan coba. Penelitian selanjutnya disarankan menggunakan kamera permanen. Variasi dosis juga dapat memberikan dampak pada korelasi antara dosis dan efek.

\section{DAFTAR PUSTAKA}

1. Longo D, Fauci A, Kasper D, Hauser S, Jameson J, an Localzo J. Harrison's ${ }^{T M}$ Principles of Internal Medicine. 18th Edition. New York, USA: The McGraw-Hill Companies; 2012; Hal. 2275-2304.

2. Chen L, Magliano DJ, and Zimmet, ZP. The Worldwide Epidemiology of Type 2 Diabetes Mellitus-Present and Future Perspectives. Nature Reviews Endocrinology. 2011; 8(4): 228-236.

3. American Diabetes Asscociation. National Diabetes Statistics Report 2014. (Online) 10 Juni 2014. htt p: / / w w w. diabetes.org / diabetes basics/statistics/\#sthash.R3F0DK4m.dpuf. [diakses tanggal 2 Januari 2016].

4. Riset Kesehatan Dasar. Badan Penelitian dan Pengembangan Kesehatan. Jakarta: Kementerian Kesehatan Republik Indonesia; 2013; hal. 87-90.

5. Yonguc GN, Dodurga Y, Adiguzel E, et al. Grape Seed Extract Has Superior Beneficial Effects than Vitamin $E$ on Oxidative Stress and Apoptosis in the Hippocampus of Streptozotocin Induced Diabetic Rats. Gene. 2015; 555(2): 119-126.

6. Kodl CT and Seaquist ER. Cognitive Dysfunction and Diabetes Mellitus. Endocrin Reviews. 2008; 29(4): 494-511.

7. Wrighten SA, Piroli GG, Grillo CA, and Reagan LP. A Look Inside the Diabetic Brain: Contributors to Diabetes-Induced Brain Aging. Biochimica et Biophysica Acta. 2009; 1792(5): 444-453.

8. Cai Z, Yan Y, Wang Y, and Tian F. Minocycline Alleviates Beta-Amyloid Protein and Tau Pathology via Restraining Neuroinflammation Induced by Diabetic Metabolic Disorder. Clinical Interventions in Aging. 2013; 8: 1089-1095.

9. Granic I, Dolga AM, Nijholta IM, Dijk GV, and Eisel UL. Inflammation and NF-KB in Alzheimer's Disease and Diabetes. Journal of Alzheimer's Disease. 2009; 16(4): 809-821.

10. Zhang Y, Xu L, He D, and Ling S. Endoplasmic StressMediated Hippocampal Neuron Apoptosis Involved in Diabetic Cognitive Impairment. BioMed Research International. 2013; 2013: 9.

11. Pedret CV, Vila AS, Mir MS, et al. Mediterranean Diet and Age-Related Cognitive Decline: A Randomised Clinical Trial. Journal of the American Medical Association Internal Medicine. 2015; 175(7): 10941103.

12. Yoshida KM, Mori M, and Kondo T. Blue Flower Color Development by Anthocyanins: from Chemical Structure to Cell Physiology. Natural Product Report. 2009; 26(7): 884-915.

13. Kahkonen MP, Hopia Al, and Heinonen M. Berry
Penelitian ini membuktikan bahwa pemberikan antosianin ubi jalar ungu (Ipomoea batatas I.) dosis $10 \mathrm{mg} / \mathrm{kgBB}$ dan $20 \mathrm{mg} / \mathrm{kgBB}$ memperbaiki fungsi memori spasial dan pada dosis $80 \mathrm{mg} / \mathrm{kgBB}$ menurunkan ekspresi TNF- $\alpha$, apoptosis sel hipokampus tikus wistar/Rattus novergicus model diabetes melitus.

Phenolics and Their Antioxidant Activity. Journal of Agricultural and Food Chemistry. 2001; 49(8): 40764082.

14. Min B, McClung AM, and Chen MH. Phytochemicals and Antioxidant Capacities in Rice Brans of Different Color. Journal of Food Science. 2011; 76(1): 117-126.

15. Gutierres JM, Carvalho FB, Schetinger MR, et al. Anthocyanins Restore Behavioral and Biochemical Changes Caused by Streptozotocin-Induced Sporadic Dementia of Alzheimer's Type. Life Sciences. 2013; 96(1): 7-17.

16. Maharani T, Sargowo J, Tjokropranowo A, and Ratnawati R. Effect of Extract Purple Ipomea Batatas Cultivar Kawi Mountain Chronic Inflammation in wistar Rats with Atherogenic Diet. International Journal of Science and Technology. 2014; 3(1): 1-7.

17. Morris RG. Spatial Localization does not Require the Presence of Local Cues. Learning and Motivation. 1981; 12(2): 239-260.

18. Terra X, Montagut G, Bustos M. et al. Grape-Seed Procyanidins Prevent Low-Grade Inflammation by Modulating Cytokine Expression in Rats Fed a HighFat Diet. Journal of Nutritional Biochemistry. 2009; 20(3): 210-218.

19. Rehman SU, Shah SA, Ali T, Chung JL, and Kim MO. Anthocyanins Reversed D-Galactose-Induced Oxidative Stress and Neuroinflammation Mediated Cognitive Impairment in Adult Rats. Molecular Neurobiology. 2017; 54(1); 255-271.

20. Ullah I, Park HY, and Kim MO. Anthocyanins Protect against Kainic Acid-induced Excitotoxicity and Apoptosis via ROS-activated AMPK Pathway in Hippocampal Neurons. CNS Neuroscience and Therapeutics. 2014; 20(4): 327-338.

21. Jo YN, Jin DE, Jeong JH, Kim HJ, Kim DO, and Heo HJ. Effect of Anthocyanins from Rabbit-Eye Blueberry (Vaccinium virgatum) on Cognitive Function in Mice under Trimethyltin-Induced Neurotoxicity. Food Science and Biotechnology. 2015; 24(3); 1077-1085.

22. Krikorian $\mathrm{R}$, Shidler MD, Nash TA, et al. Blueberry Supplementation Improves Memory in Older Adults. Journal of Agricultural Food Chemistry. 2010; 58(7): 3996-4000.

23. Mirshekar $M$, Roghani $M$, Khalili $M$, Baluchnejadmojarad T, and Arab MS. Chronic Oral Pelargonidin Alleviates Learning and Memory Disturbances in Strptozotocin Diabetic Rats. Iranian Journal of Pharmaceutical Research. 2011; 10(3): 569-575.

24. Williams CM, El Mohsen MA, Vauzour D, et al. Blueberry -Induced Changes in Spatial Working Memory Correlate with Changes in Hippocampal 
CREB Phosphorylation and Brain-Derived Neurotrophic Factor (BDNF) Levels. Free Radical Biology Medicine. 2008; 45(3): 295-305.

25. Murphy T, Dias GP, and Thuret S. Effects of Diet on
Brain Plasticity in Animal and Human Studies: Mind the Gap. Neural Plasticity. 2014; 2014: 1-32.

26. Good M. Spatial Memory and Hippocampal Function: Where are We Now? Psicologica. 2002; 23: 109-138. 